\title{
Woodland Conversion by Elephants in Africa: The Search for Causal Factors, Processes, Mechanisms and Management Strategies
}

\author{
Paul Zyambo \\ National Parks and Wildlife, Conservation and Management, Chilanga, Zambia \\ Email: paulzya@yahoo.com
}

Received 24 December 2015; accepted 24 January 2016; published 27 January 2016

Copyright (C) 2016 by author and Scientific Research Publishing Inc.

This work is licensed under the Creative Commons Attribution International License (CC BY). http://creativecommons.org/licenses/by/4.0/

(c) (i) Open Access

\section{Abstract}

The impacts of elephants on woodlands have triggered concerns that elephants were converting woodlands to grasslands in African savannas leading to the loss of biodiversity. Therefore, the objectives of the study are to identify the causes, processes and impacts of woodland conversion by elephants and thereby propose a guideline for formulating management strategies. The study is conducted through reviewing published documents on elephant-woodland interaction, factors, mechanisms and processes of woodland conversion to grasslands and impacts on biodiversity have been identified. The study reveals that: 1) the large nutritional and energetic requirements by elephants and high elephant population densities are two driving forces that may cause elephants to convert woodlands to grasslands; 2) the process of woodland conversion is not just elephant-tree interaction, but usually included other agents such as fires, droughts or other herbivores. Woodlands are converted to grasslands or scrublands because elephants, fires, droughts and other herbivores prevent recruitment of tree to larger class sizes and regeneration of seedlings of woody plants; 3 ) whereas there are few studies that support biodiversity decline due to impacts of elephants on woodlands, there are studies that indicate woodland disturbance by elephants have benefited and increased diversity of other species. It is concluded that woodland disturbance by elephant is not always detrimental to biodiversity, but may create heterogeneity and suitable habitats for other species. In formulating management strategies, considerations must be made to elephant densities, other agents that interact or work with elephants in woodland conversion and the benefits of woodland changes to biodiversity due to elephants.

\section{Keywords}

Biodiversity, Density, Elephants, Grasslands, Herbivores, Woodland Conversion 


\section{Introduction}

The African elephant (Loxodonta Africana (Blumenbach)) is considered a mega-herbivore and keystone species whose activities and extinction can cause profound changes or extinctions in ecosystems [1] [2]. In southern and eastern Africa, elephants have converted woodlands and bushlands to scrublands, wooded grasslands and grasslands [3]-[7]. Woodland loss or conversion is considered as a major cause of biodiversity decline in protected areas of African savanna [2] [8] [9]. It is also suggested that the conversion of woodlands to grasslands by elephants will result in detrimental consequences on the population of elephants themselves [3] [4]. Furthermore, economic loss of timber in some forest and savanna areas in Africa has been associated with the loss of woody vegetation due to elephants [3] [10] [11]. However, despite the ecological importance of elephants in opening up forests and woodlands and thus creating favourable habitats for other species, there has been much focus on woodland conversion by elephants that leads to biodiversity loss [2]. This is probably because most studies on elephant-woodland interaction have been conducted in areas where elephant impacts on woody vegetation are drastic.

Several hypotheses and factors have been advanced to explain why and how elephants convert woodlands to scrublands, wooded grassland or grasslands. Consequently, there have been debates on whether the process of woodland conversion by elephants is natural or not [9]. Debates have extended further to the appropriateness of some interventions by humans in controlling or halting the conversion process [12]. Thus, the management of elephants and consequently their impact on vegetation have attracted the international attention.

The woodland conversion by elephants in protected areas has presented a major concern and challenge to the conservationists and wildlife managers in African savannas. This is mainly because conservation of biodiversity is usually the highest priority function of protected areas and can be highly compromised if issues of woodland conversion are not appropriately addressed. Therefore understanding the process and reasons why elephants have profound impact on woodlands is critical when formulating strategies for addressing the problem. In this study, I will synthesis the causes and processes of woodland conversion by elephants from published documents and suggest how the elephant-woodland problem can be managed. This study is restricted to the African tropical region covering forests and savannas. I will approach this study by addressing three pertinent objectives through review of literature on the interactions of elephants with woody vegetation in African forests and savannas. The three study objectives are: 1) to identify the causes and processes of woodland conversion by elephants; 2) to determine the impacts of woodland conversion by elephants on biodiversity and 3) to propose factors that can be considered in formulating strategies for addressing woodland conversion by elephants.

\section{Causes and Processes of Woodland Conversion by Elephants}

\subsection{Factors and Mechanisms of Woodland Conversion}

Several probable factors and hypotheses that explain the processes and why the largest land mammal in Africa converts woodlands to scrublands, wooded grassland or grasslands have been advanced. First, it has been suggested that elephants at high densities in some areas in eastern and southern Africa have converted forests, savanna woodlands and bushlands into wooded grassland, scrublands and grasslands [4]-[6]. Elephant densities that are considered high and associated with woodland changes have ranges from approximately above 0.5 elephant $/ \mathrm{km}^{2}$ to 6.0 or more elephants $/ \mathrm{km}^{2}$ [2] [5] [8]. The increase in elephant densities in some areas is due to natural growth, immigration from areas with increasingly human disturbances, and immigration to areas with preferred habitat types and availability of water points, mineral licks, plant species for food and adequate shade from sun heat in dry season [13]-[17]. The high elephant density premise is popularly explained by the compression hypothesis which indicates that the compression of elephants is due to expanding human population and activities which cause high concentration of elephants in protected areas resulting in drastic damage on woody vegetation [1]-[3] [5] [7] [15] [18]. Hayward \& Zawadzka [19] found that increasing elephant density was more influential in reducing vegetation condition than rainfall amounts in Kruger National Park. Therefore, high elephant density seems to be a precursor to the process of woodland conversion by elephants.

The elephant forage quality, which varies with seasons in African savannas, is a second factor that has been proposed to explain why elephants damage woody plants. Holdo [20] found that in western Zimbabwe, elephant damage on woody plants was positively correlated with leaf calcium, magnesium, potassium and protein concentration. Observations in savanna habitats suggest that most elephant damage on woody plants occur in dry 
season when woody browse constitutes a large proportion of elephants' diet [21]-[24]. In wet season, grasses constitute $70 \%$ of elephant diet, but progressively shift to more browse proportion in dry season [25]. This is probably because grasses tend to rapidly become fibrous as dry season progresses, thereby diluting the nutrient content and therefore elephants turn to browse which is a critical dry season food reserve as its crude content is then higher than that of grasses [14] [26] [27]. Furthermore, Guy [21] [22] and Barnes [23] indicated that debarking of trees by elephants frequently occurs during late dry season when there is increased nutrient translocation from roots to new foliage and flowering parts. Therefore a key factor in the process of woodland conversion is the elephants' critical nutritional requirements.

Another hypothesis advanced to explain the impact of elephants on woody vegetation is the maladapted feeding strategy hypothesis [13] where tree felling by elephants appeared to be part of feeding strategy that leads to increase of browse production of preferred height classes and species and improves availability of food to elephants in dry season [14] [28]. Jachmann and Bell [13] postulated that most of the present-day elephant populations probably evolved in the moist oligotrophic forests and Guinea woodland of Central Africa where increasing browse availability following pushover of trees is an appropriate feeding strategy. Kohi et al. [29] found that impacts of elephant on woodlands facilitated redistribution and availability of browse and improved quality thereby benefiting herbivores in Kruger National Park. Hence the observed tree felling by elephants in savannas represents a feeding strategy. However, Croze [30] and Guy [21] indicated that uprooting and pushing over of trees by elephants appeared to be more of a social display than a feeding necessity.

The major elephant activities associated with drastic damage and mortality of woody plants are tree felling through pushing over and uprooting, and debarking which involves bark-stripping or ring-barking [4] [5] [24] [31]. Stem and branch breaking by elephants are usually responsible for altering woody plant growth form to that of coppiced, stunted and forked [4] [31]. The mechanisms by which elephants reduce woodlands are either through preventing woodland regeneration of seedlings or preventing recruitment into larger size classes. Dublin et al. [18] reported that in 1980s elephants alone appeared to prevent woodland regeneration in Mara area by feeding on small saplings because there were few trees in larger height classes. However, in the same area in 1960s, elephants largely ignored saplings under 1m because trees in larger height classes were relatively many [18] [30] [32]. Barnes [6] also reported that elephants prevented regeneration of Acacia albida and Commiphora ugogensis in Ruhua National Park in Tanzania. It implies that when woodlands are sensitive to impacts on regenerating seedlings than those of mature trees, the prevention of woodland regeneration by elephants can have profound consequences of woodland loss [18]. In contrast, Caughley [4] concluded that elephants were preventing recruitment of Colophospermum mopane into taller size classes rather than limiting regeneration because regenerating seedlings were abundant and elephants were heavily browsing plants when they grew to above $1 \mathrm{~m}$ in Luangwa valley. Campbell et al. [11] also reported that elephants in northwest Matebeleland in Zimbabwe were limiting recruitment of Pterocarpus angolensis into exploitable timber size classes. When regeneration or/and recruitment rates are lower than mortality rates of impacted seedlings and trees by elephants, woodlands declined to grasslands [18].

\subsection{The Ecological Processes of Woodland Conversion}

Several ecological processes that are associated with the influence of elephants have been proposed to explain the woodland dynamics in African savannas. The first process is a direct cyclic elephant-plant interaction advanced by Caughley [4]. Caughley [4] hypothesised the impact and response relationship between trees and elephants that follow a stable limit cycle of a periodicity of about 200 years in the Luangwa valley, Zambia. In this model, elephants at high densities will reduce woodland cover and thereby reduce habitat quality that subsequently results in reduced elephant numbers [4]. However, Duffy et al. [33] assessed this model by using a wide range of realistic parameters estimated and found that the limit cycles were highly unlikely. Besides lacking empirical evidence, this model is simple as it has only elephant as the agent for woodland decline. Western \& Maitumo [9] also indicated that in Amboseli National Park, elephants were the only factor preventing woodland recovery.

The second ecological process is described as multiple stable states model. Dublin et al. [18] proposed that there are two stable states, grasslands and woodlands, in savannas and elephant and fire are necessary for permanent shift from one state to another. However, fire is suggested as a primary agent in the shifting woodland to grassland whereas elephants prevent grasslands from shifting to woodlands. In this model elephant and fire are 
necessary for a permanent shift from woodland to grassland and vice versa [18].

The third model of the ecological process of woodland conversion proposes the influence of elephant and other herbivores acting concurrently on woody plants in preventing regeneration and recruitment. The decline in woodland in northern parts of Chobe National Park in Botswana has been attributed to herbivory by increasing elephants and large impala (Aepyceros melampus) populations [34] [35]. Moe et al. [36] found that seedlings were primarily predated on by impalas and thereby prevented regeneration of trees in the elephant-transformed Chobe woodland of northern Botswana. The influence of fire was not considered as a dominant factor in northern Chobe National Park [34]. However, Pellew [37] reported that while elephant caused mortality to mature Acacia tortilis trees in woodlands of Serengeti, giraffe (Giraffa camelopardelis) and frequent fires prevented regeneration development. It has also been found in East Africa that smaller or medium-sized herbivores were responsible for preventing woodland regeneration instead of fire or elephants [38] [39].

The fourth ecological process of woodland conversion involves drought, fire and elephant. Van de Vijver et al. [40] reported a large decline in the density of small trees over twenty-five years in Tarangire National Park in Tanzania due to severe drought, when elephants only affected tree size distribution, and fire was not a major cause of woodland change. In this process, the influence of drought was more important than that of fire and elephants. In northern Botswana, drought probably contributed in causing herbivores to concentrate along water points resulting in heavy browsing impact on vegetation [34].

Fifthly, Van der Koppel \& Prins [41] proposed that the interaction of herbivores such as competition and facilitation could provide an alternative explanation for the African savanna woodland dynamics. They claimed that competition for grazing between elephants and other abundant herbivores such as buffalo (Syncerus caffer) and wildebeest (Connochaetes taurinus) would result in elephants over-browsing woodlands in dry season. Van der Koppel \& Prins [41] indicated that elephants react to competition with other abundant large herbivores by shifting from grazing to browsing and consequently over-utilise woody plants. However, the shift from graze to browse by elephants in dry season is also explained in terms of reduced forage quality in grasses during dry season.

Therefore, woodland conversion process that is associated with elephants in savannas may involves factors such as herbivory by other herbivores, fires or droughts. Asner \& Levick [42] found that apart from elephants and fire, long-term climate and substrate fertility also influence herbivore-mediated tree turnover at landscape scale in African savanna. While elephants usually cause mortalities to mature trees, fires, droughts and the other herbivores normally prevent regeneration establishment of seedlings. The combined impact of elephants, other herbivores, fires and droughts converts woodlands to scrublands or grasslands. The same factors may exert their influence in maintaining the equilibrium at grassland or scrubland state (see [36]). Therefore, conversion of woodland to scrubland or grassland and maintenance at the converted state may not be entirely due to elephants alone in most cases in the African savannas.

\section{Impacts of Woodland Conversion by Elephants}

It has been suggested that elephant-mediated woodland loss or conversion is a major cause of overall biodiversity decline in African savanna protected areas [2] [8] [9]. Western [2] indicated that in Amboseli National Park, few plants dominated by one or two were found in areas with exceptionally high elephant densities that exerted high disturbance levels. He further pointed out that areas with moderate elephant densities (therefore lower disturbance levels) had two or three times as many species contributing to more evenly total plant abundance. Cumming et al. [8] investigated the impact of elephant-mediated woodland degradation in Zimbabwe by comparing species richness in degraded and undegraded woodlands. They found that degraded woodland had significantly lower species richness of woodland birds, ants and woody plants of over $3 \mathrm{~m}$ in height. Kerley and Landman [43] concluded that there was an overall decline in biodiversity with significant decrease of plant species richness due to elephant impacts in Addo Elephant National Park, South Africa. However, the impact of elephant-mediated woodland conversion on biodiversity has rarely been measured in the African savannas [9] and thereby limiting direct evidence of decline of overall biodiversity due to elephant-mediated woodland conversion.

The impacts of woodland disturbance by elephants on individual or few species have been documented elsewhere in African savannas. In Amboseli National Park, there was a significant decrease in browser and mixed feeder biomass of giraffe, impala and Grant's gazelle (Gazella granti) in areas where elephants reduced wood- 
lands and expanded grasslands [2]. In Botswana, along the Chobe riverfront, the bushbuck (Tragelaphus scriptus) population declined due to the drastic riverine woodland disturbance by elephants [35]. The decline of bushbuck was linked to the loss of bushbuck habitat resulting from herbivory activities from elephants. Likewise, in Addo Elephant National Park, the numbers of Cape grysbok (Raphicerus melanotis), bushbuck and bushpig (Potamochoerus porcus) declined probably as a result of changes in the habitat structure caused by elephants [43]. Furthermore, Gandiwa et al. [44] reported that mean tree densities, basal areas, tree heights and species diversity were lower in areas with increased damaged plants by elephants in the Acacia tortilis woodland in southeast Zimbabwe. However, Rutina et al. [45] found that the converted woodland to shrubland by elephants improved the dry-season browse availability for impalas, which increased in numbers as a result. Valeix et al. [46] also reported that elephant-induced vegetation changes influenced selection by browsers for microhabitats with modified vegetation. Similarly, Stokke et al. [47] found that small/medium sized mammals and gallinaceous birds in Chobe may have benefited from impacts of elephants, through increasing the shrubland habitats.

\section{Management Strategies}

The challenges that woodland conversion by elephants presents to the conservationists and wildlife managers have resulted in drastic measures being taken to address them. It seems management strategies to prevent woodland conversion in Africa have been placed on reducing numbers of elephants through culling, translocations, range expansions, manipulations of water sources, and contraceptives [48] [49]. Elephant culling has been employed in Namibia, South Africa, Zambia and Zimbabwe in the last 45 years, but have been met with pro and anti culling debates. These strategic measures have concentrated on the reducing elephant numbers without considering other agents that might have worked with elephants in changing woodlands. Accordingly, proposals for alternative measures such as creation of mega parks and linking conservation landscapes to facilitate movements and dispersal of elephants have been made [48] [50] [51].

\section{Discussion}

\subsection{Factors, Mechanisms and Processes of Woodland Conversion}

Three main factors that cause elephants to profoundly disturb woodlands and convert them to scrublands, wooded grasslands and grasslands have been identified. The first and probably the most important factor is the high elephant population densities that range from approximately above 0.5 elephant $/ \mathrm{km}^{2}$ to 6.0 or more elephants $/ \mathrm{km}^{2}$ [2] [5] [8]. All woodland disturbances that resulted in conversion to grasslands occurred when elephant densities were within the above reported density range. High elephant densities in most African wildlife protected areas are due to compression of elephant habitats resulting from human population growth and activities. However, natural elephant population growth and other factors also valid in other areas like Botswana. The second factor is the elephant nutritional and energetic requirements. Due to their large body size elephants require large absolute value of energy and minerals for activities and body maintenance. Elephants spend up to 90\% of their time foraging and consume between $100 \mathrm{~kg}$ and $300 \mathrm{~kg}$ (wet mass) of vegetation per day [22] [52]. This huge nutritional and energetic requirement by elephants exerts pressure on the vegetation of a particular habitat where elephant densities are high due to concentration effect. Related to elephant nutritional and energetic requirements is the third factor which is the seasonal variation in elephant forage quality in graze and browse materials. When graze forage quality declines towards the end of wet season, elephants reduce graze and increase browse material intake and thereby increase disturbances to woody plants [14] [21]-[23] [26] [27]. The second and third factors influence the optimal foraging behaviour by elephants. I suggest that the drivers for huge impact on woody plants by elephants are elephants' high population densities and optimal foraging behaviour.

The proposal that elephants push over and uproot trees for social display rather than feeding necessity [21] [30] may not be accepted as another factor mainly because it has no tested evidence. However, pushing over and uprooting trees has been described as being part of elephant feeding strategy [13] [14] [28]. If pushing over and uprooting trees is a social display, it is then associated with feeding behaviour strategy. The exercise of pushing over and uprooting trees should be a cost to elephants in terms of energy, and therefore engaged only when its benefits outweigh the costs. It is probable that acquisition of energy and minerals from pushed over and uprooted trees provides net energetic and nutritional benefits to elephants.

The elephant-mediated woodland dynamics in the African savannas are ecological processes that involve in- 
teractions of biotic and non-biotic components. The woodland conversion processes are not usually as simple as an elephant-tree only interaction as suggested by Caughley [4] in his stable limit cycle hypothesis. However, in this review woodland conversion is usually an interaction involving more than trees and elephants. Evidence from eastern and southern Africa indicates that droughts, fires or other herbivores act or interact with elephants in converting woodlands [18] [34] [35] [37] [40]. Moreover in some areas elephants were not the primarily agents in the woodland conversion [18] [40]. The mechanism of woodland conversion to grassland operates when agents of conversion prevent tree recruitment into larger size classes through increasing adult tree mortalities or/and prevent regeneration development of seedlings. The decline of woodland depends on how regeneration and recruitment rates compare or differ with mortality rates of impacted seedlings and adult trees [18]. Therefore, it implies that regeneration or/and recruitment rates have been lower than mortality rates of impacted seedlings and trees in areas where woodlands have declined due to elephants.

\subsection{Impacts of Woodland Conversion}

The major concern of conservationists and wildlife managers on woodland conversion by elephants is the consequent decline of overall biodiversity. However, there are very few field studies done that support the decline of overall biodiversity due to elephant-mediated woodland conversions to grasslands. The study by Cumming et al. (1997) indicated that woodland degradation had significant negative impacts only on species richness of woodland birds, ants and woody plants of over $3 \mathrm{~m}$ in height. Furthermore, most studies have indicated the impact of woodland disturbances by elephants on just individual or few species of animals or plants (see [2] [35] [43] [44]). Therefore due to limited direct evidence of negative impacts of elephant-mediated woodland conversion on the overall biodiversity, deductions are usually derived from other sources such as deforestation or human-caused woodland degradation.

It has been shown that woodland disturbance by elephants might be beneficial to the overall biodiversity especially when the level of disturbance is moderate. Western [2] indicated that at moderate elephant densities (with moderate disturbance levels) in some parts of Amboseli National Park increased species richness and diversity. He further indicated that most equitable mix of grazers and browsers was found in the mosaic of woodlands associated with moderate elephant densities (and thus moderate disturbance levels) in Amboseli National Park. This supports the intermediate disturbance hypothesis proposed by Connell [53] and Huston [54]. Elephant-mediated woodland conversions have resulted in increased habitat heterogeneity that has improved browse availability and quality for variety of animal species [29] [45] [55].

\subsection{Strategic Management Implications}

This review has identified important factors and processes that have management implications. To prevent or reverse elephant-mediated woodland conversion, management strategy must consider these factors and processes to ensure conservation of biodiversity is not compromised. Therefore, when formulating strategies the following must be considered.

Firstly, high elephant population density is a precursor to the process of woodland conversion to grassland. However, high elephant densities are not always due to compression resulting from human population growth and activities. High elephant population densities may arise due to natural population growth or other factors. In Botswana, for example, concentration of elephants in northern Chobe National Park is due to natural population growth and possibly drought [34] [35]. Where high elephant density is a result of compression due to human population growth and activities, it might be necessary to open up critical corridors, expand the range and consider land-use planning in the strategy to allow dispersal and access to critical habitats and food resources for elephants. Same measures may be considered when elephant conservation efforts eventually result in increased elephant densities.

Secondly, elephants do not solely drive the process of woodland conversion to grasslands since other herbivores, fires or droughts are usually involved. Examples abound in Africa where fires, other herbivores or droughts were primary agents or worked with elephants in the process of woodland conversion [18] [34] [35] [37] [40] [56]. In this case, if the strategy targets elephants only, it might not be effective in addressing the problem of woodland conversion since the influences of other agents may persist. Therefore it is necessary that all causal agents operating in a local situation are identified and managed accordingly.

Thirdly, elephants, fires, other herbivores or episodic droughts may independently or interactively work together in the process of woodland conversion. This presents a complex process that might be difficult to clearly 
predict. This situation requires an adaptive management style where interventions applied are monitored and changed when targets or thresholds are reached. This calls for establishment of critical thresholds such as parameters of elephant population density, tree densities, species richness, fire frequency and intensity, population densities of other herbivores and rates of change in vegetation cover.

Fourthly, the management intervention should aim at ensuring that rates of tree recruitment into large size classes and seedling regeneration are higher than mortality rates of older trees and seedlings. This can be achieved by reducing mortality rates of impacted seedlings and older trees. This might include reducing population densities of elephants and other identified herbivores and changing the fire regime (frequency, seasonality and intensity) of the area. These measures should be applied following the adaptive management style where critical thresholds are used to monitor the desired effects of interventions.

Fifthly, the disturbance caused by elephants to woodlands is not always detrimental to biodiversity. Elephants open up forests and woodlands and thus creating heterogeneity and favourable habitats for other species. It is probable that woodland disturbance by elephants in the northern part of Chobe National Park has created favourable habitats and facilitated the reported population increases in buffalo, impala, greater kudu (Tragelaphus strepsiceros), small/medium-sized mammals and gallinaceous birds [45] [47]. Therefore, woodland disturbance by elephants might be beneficial or detrimental to biodiversity depending on the level of disturbance. According to the intermediate disturbance hypothesis [53] [54], the greatest species richness at any one point is likely to result from intermediate levels of disturbance. Accordingly, at either very low or high disturbance levels you expect fewer species. Therefore, the critical threshold levels for intermediate disturbance by elephants should be identified. This will requires monitoring indicators and adaptively employ appropriate interventions to maintain intermediate disturbance levels. The conservation authority of Kruger National Park in South Africa adopted the principles of intermediate disturbance hypothesis in the management of elephants for achieving maximum biodiversity [12].

\section{Acknowledgements}

I wish to express my gratitude to Professor Stein R. Moe who provided valuable comments to this paper, which was first drafted when I was at the Norwegian University for Life Sciences. He encouraged me to have it published.

\section{References}

[1] Owen-Smith, N. (1989) Megafaunal Extinctions: The Conservation Message from 11,000 Year B.P. Conservation Biology, 3, 405-412. http://dx.doi.org/10.1111/j.1523-1739.1989.tb00246.x

[2] Western, D. (1989) The Ecological Role of Elephants in Africa. Pachyderm, 12, 42-45.

[3] Laws, R.M. (1970) Elephants as Agents of Habitat and Landscape Change in East Africa. Oikos, 21, 1-5. http://dx.doi.org/10.2307/3543832

[4] Caughley, G. (1976) The Elephant Problem—An Alternative Hypothesis. East Africa Wildife Journal, 13, 39-48. http://dx.doi.org/10.1111/j.1365-2028.1975.tb00122.x

[5] Cumming, D.H.M. (1982) The Influence of Large Herbivores on Savanna Structure in Africa. In: Huntley, B.L. and Walker, B.H., Eds., Ecology of Tropical Savannas, Spring-Verlag, 217-245. http://dx.doi.org/10.1007/978-3-642-68786-0_11

[6] Barnes, R.F.W. (1983) Effects of Elephant Browsing on Woodlands in a Tanzanian National Park: Measurements, Models and Management. Journal of Applied Ecology, 20, 521-540. http://dx.doi.org/10.2307/2403524

[7] Western, D. and Gichohi, H. (1993) Segregation Effects and Impoverishment of Savanna Parks: The Case for Ecosystem Viability Analysis. African Journal of Ecology, 31, 269-281. http://dx.doi.org/10.1111/j.1365-2028.1993.tb00541.x

[8] Cumming, D.H.M., Fenton, M.B., Rautenback, I.L., Taylor, R.D., Cumming, G.S., Cumming, M.S., Dunlop, J.M., Ford, A.G., Hovorka, M.D., Johnston, D.S., Kalcounis, M., Mahlangu, Z. and Portfors, C.V.R. (1997) Elephants, Woodlands and Biodiversity in Southern Africa. South African Journal of Science, 93, 231-236.

[9] Western, D. and Waitumo, D. (2004) Woodland Loss and Restoration in a Savanna Park: A 20 Year Experiment. African Journal of Ecology, 42, 111-121. http://dx.doi.org/10.1111/j.1365-2028.2004.00506.x

[10] Afolayan, T.A. (1975) Effects of Elephant Activities on Forest Plantations in Kilimanjaro Forest Game Reserve in Northern Tanzania. Oikos, 26, 404-410. http://dx.doi.org/10.2307/3543514 
[11] Campbell, B.M., Butler, J.R.A., Mapaure, I., Vermeulen, S.J. and Mashove, P. (1996) Elephant Hunting and Safari Hunting in Pterocarpus angolensis Woodland in Northwest Matebeleland, Zimbabwe. African Journal of Ecology, 34, 380-388. http://dx.doi.org/10.1111/j.1365-2028.1996.tb00633.x

[12] Whyte, I.J. (2004) Ecological Basis of New Elephant Management Policy for Kruger National Park and Expected Outcomes. Pachyderm, 36, 99-108.

[13] Jachmann, H. and Bell, R.H.V. (1984) Why Do Elephants Destroy Woodlands? African Elephant and Rhino Group Newsletter, 3, 9-10.

[14] Bell, R.H.V. (1985) Elephant and Woodlands-A Reply. Pachyderm, 5, 17-18.

[15] Lewis, D.M. (1986) Disturbance Effect on Feeding: Evidence for Compression in Luangwa Valley, Zambia. African Journal of Ecology, 24, 227-241. http://dx.doi.org/10.1111/j.1365-2028.1986.tb00367.x

[16] Viljoen, P.J. (1989) Habitat Selection and Preferred Food Plants of a Desert-Dwelling Elephant Population in the Northern Namib-Desert, South West Africa/Namibia. African Journal of Ecology, 27, 227-240. http://dx.doi.org/10.1111/j.1365-2028.1989.tb01016.x

[17] Conybeare, A.H. (1991) Elephant Occupancy and Vegetation Change in Relation to Artificial Water Points in a Kalahari Sand Area of Hwange National Park. Ph.D. Thesis, University of Zimbabwe.

[18] Dublin, H.T., Sinclair, A.R.E. and Mcglade, J. (1990) Elephant and Fire as Causes of Multiple Stable States in the Serengeti-Mara Woodlands. Journal of Animal Ecology, 59, 1147-1164. http://dx.doi.org/10.2307/5037

[19] Hayward, M.W. and Zawadzka, B. (2010) Increasing Elephant Loxodonta Africana Density Is More Important Driver of Change in Vegetation Condition than Rainfall. Acta Theriologica, 55, 289-299. http://dx.doi.org/10.4098/j.at.0001-7051.076.2009

[20] Holdo, R.M. (2003) Woody Plant Damage by African Elephant in Relation to Leaf Nutrients in Western Zimbabwe. Journal of Tropical Ecology, 19, 189-196. http://dx.doi.org/10.1017/S0266467403003213

[21] Guy, P.R. (1976) The Feeding Behaviour of Elephant (Loxondata africana) in the Sengwa Area, Rhodesia. South Africa Journal of Research, 6, 55-63.

[22] Guy, P.R. (1976) Diurnal Activity Patterns of Elephants in the Sengwa Area, Rhodesia. East Africa Wildlife Journal, 14, 285-295. http://dx.doi.org/10.1111/j.1365-2028.1976.tb00243.x

[23] Barnes, R.F.W. (1982) Elephant Feeding Behaviour in Ruhua National Park, Tanzania. African Journal of Ecology, 20, 123-136. http://dx.doi.org/10.1111/j.1365-2028.1982.tb00282.x

[24] Kabigumila, J. (1993) Feeding Habits of Elephants in Ngorongoro Crater, Tanzania. African Journal of Ecology, 31, 156-164. http://dx.doi.org/10.1111/j.1365-2028.1993.tb00528.x

[25] Poole, J. (1994) The African Elephant. In: Kangwana, K., Ed., Studying Elephants, African Wildlife Foundation, Nairobi, 1-8.

[26] Bell, R.H.V. (1971) A Grazing Ecosystem in the Serengeti. Science America, 225, 86-93. http://dx.doi.org/10.1038/scientificamerican0771-86

[27] Field, C.R. (1971) Elephant Ecology in the Queen Elizabeth National Park, Uganda. East Africa Wildlife Journal, 9, 99-123. http://dx.doi.org/10.1111/j.1365-2028.1971.tb00223.x

[28] Jachmann, H. and Bell, R.H.V. (1985) Utilisation by Elephants of Brachystegia Woodlands of Kasungu National Park, Malawi. African Journal of Ecology, 23, 245-258. http://dx.doi.org/10.1111/j.1365-2028.1985.tb00955.X

[29] Kohi, E.M., de Boer, W.F., Peel, M.J.S., Slotow, R., Van Der Waal, C., Heitkönig, I.M.A., Skidmore, A. and Prins, H.H.T. (2011) African Elephants Loxodonta africana Amplify Browse Heterogeneity in African Savanna. Biotropica, 43, 711-721. http://dx.doi.org/10.1111/j.1744-7429.2010.00724.x

[30] Croze, H. (1974) The Seronera Bull Problem I. The Elephants. East African Wildlife Journal, 12, 1-27. http://dx.doi.org/10.1111/j.1365-2028.1974.tb00104.x

[31] Lewis, D.M. (1991) Observations of Tree Growth, Woodland Structure and Elephant Damage on Colophospermum mopane in Luangwa Valley, Zambia. African Journal of Ecology, 29, 207-221. http://dx.doi.org/10.1111/j.1365-2028.1991.tb01003.x

[32] Croze, H. (1974) The Seronera Bull Problem II. The Trees. East African Wildlife Journal, 12, 29-47. http://dx.doi.org/10.1111/j.1365-2028.1974.tb00105.x

[33] Duffy, K.J., Page, B.R., Swart, J.H. and Bajić, V.B. (1999) Realistic Parameter Assessment for a Well-Known Elephant-Tree Ecosystem Model Reveals That Limit Cycles Are Unlikely. Ecological Modelling, 121, 115-125. http://dx.doi.org/10.1016/S0304-3800(99)00091-5

[34] Mosugelo, D.K., Moe, S.R., Ringrose, S. and Nellemann, C. (2002) Vegetation Changes during a 36-Year Period in Northern Chobe National Park, Botswana. African Journal of Ecology, 40, 232-240. http://dx.doi.org/10.1046/j.1365-2028.2002.00361.x 
[35] Skarpe, C., Aarrestad, P.A., Andreassen, H.P., Dhillion, S., Dimakatso, T., du Toit, J.T., Halley, D.J., Hytteborn, H., Makhabu, S., Mari, M., Marokane, W., Masunga, G., Modise, D., Moe, S.R., Mojaphoko, R., Mosugelo, D., Motsumi, S., Neo-Mahupeleng, G., Ramotadima, M., Rutina, L., Sechele, L., Sejoe, T.B., Stokke, S., Swenson, J.E., Taolo, C., Vandewalle, M. and Wegge, P. (2004) The Return of the Giants; Ecological Effects of an Increasing Elephant Population. Ambio, 33, 276-282. http://dx.doi.org/10.1579/0044-7447-33.6.276

[36] Moe, S.R., Rutina, L.P., Hytteborn, H. and du Toit, J.T. (2009) What Controls Woodland Regeneration after Elephants Have Killed the Big Trees? Journal of Applied Ecology, 46, 223-230. http://dx.doi.org/10.1111/j.1365-2664.2008.01595.x

[37] Pellew, R.A.P. (1983) The Impacts of Elephant, Giraffe and Fire upon the Acacia tortilis Woodlands of the Serengeti. African Journal Ecology, 21, 41-74. http://dx.doi.org/10.1111/j.1365-2028.1983.tb00311.x

[38] Belsky, A.J. (1984) Role of Small Browsing Mammals in Preventing Woodland Regeneration in the Serengeti National Park, Tanzania. African Journal of Ecology, 22, 271-279. http://dx.doi.org/10.1111/j.1365-2028.1984.tb00701.x

[39] Prins, H.H.T. and Van Der Jeugd, H.P. (1993) Herbivore Population Crashes and Woodland Structure in East Africa. Journal of Ecology, 81, 305-314. http://dx.doi.org/10.2307/2261500

[40] Van de Vijver, C.A.D.M., Foley, C.A. and Olff, H. (1999) Changes in the Woody Component of an East African Savanna during 25 Years. Journal of Tropical Ecology, 15, 545-564. http://dx.doi.org/10.1017/S0266467499001017

[41] Van Der Koppel, J. and Prins, H.H.T. (1998) The Importance of Herbivore Interactions for the Dynamics of African Savanna Woodlands: An Hypothesis. Journal of Tropical Ecology, 14, 565-576. http://dx.doi.org/10.1017/S0266467498000406

[42] Asner, G.P. and Levick, S.R. (2012) Landscape-Scale Effects of Herbivores on Treefall in African Savannas. Ecology Letters, 15, 1211-1217. http://dx.doi.org/10.1111/j.1461-0248.2012.01842.x

[43] Kerley, G.I.H. and Landman, M. (2006) The Impacts of Elephants on Biodiversity in the Eastern Cape Subtropical Thickets. South African Journal of Science, 102, 395-402.

[44] Gandiwa, E., Magwati, T., Zisadza, P., Chinuwo, T. and Tafangenyasha, C. (2011) The Impact of African Elephants on Acacia tortilis Woodland in Northern Gonarezhou National Park, Zimbabwe. Journal of Arid Environments, 75, 809814. http://dx.doi.org/10.1016/j.jaridenv.2011.04.017

[45] Rutina, L.P., Moe, S.R. and Swenson, J.E. (2005) Elephant Loxodonta africana Driven Woodland Conversion to Shrubland Improves Dry-Season Browse Available for Impalas Aepyceros melampus. Wildlife Biology, 11, 207-213. http://dx.doi.org/10.2981/0909-6396(2005)11[207:ELADWC]2.0.CO;2

[46] Valeix, M., Fritz, H., Sabatier, R., Murindagomo, F., Cumming, D. and Duncan, P. (2011) Elephant-Induced Structural Changes in the Vegetation and Habitat Section by Large Herbivores in an African Savanna. Biological Conservation, 144, 902-912. http://dx.doi.org/10.1016/j.biocon.2010.10.029

[47] Stokke, S., Motsumi, S.S., Sejoe, T.B. and Swenson, J.E. (2014) Cascading Effects on Smaller Mammals and Gallinaceous Birds of Elephant Impacts on Vegetation Structure. In: Skarpe, C., du Toit, J.T. and Moe, S.R., Eds., Elephants and Savanna Woodland Ecosystems: A Study from Chobe National Park, Botswana, John Wiley \& Sons Ltd., Chichester, 229-250. http://dx.doi.org/10.1002/9781118858615.ch14

[48] Van Aarde, R.J., Jackson, T.P. and Ferreira, S.M. (2006) Conservation Science and Elephant Management in Southern Africa. South African Journal of Science, 102, 385-388.

[49] Balfour, D., Dublin, H.T., Fennessy, J., Gibson, D., Niskanen, L. and Whyte, I.J., Eds. (2007) Review of Options for Managing the Impacts of Locally Overabundant African Elephants. IUCN, Gland, 80 p.

[50] Caughley, G. (1981) Overpopulation. In: Jewell, P.A. and Holt, S., Eds., Problems in Management of Locally Abundant Wild Mammals, Academic Press, New York, 91-118. http://dx.doi.org/10.1016/b978-0-12-385280-9.50008-1

[51] Kerley, G.I.H., Wilson, S. and Massey, A. (2006) Elephant Conservation and Management in the Eastern Cape. Report No. 35, Terrestrial Ecology Research Unit, University of Port Elizabeth, Port Elizabeth.

[52] Wyatt, J.R. and Eltringham, S.K. (1974) The Daily Activity of the Elephant in the Rwenzori National Park, Uganda. East African Wildlife Journal, 12, 273-289. http://dx.doi.org/10.1111/j.1365-2028.1974.tb01037.x

[53] Connell, J.H. (1978) Diversity in Tropical Rain Forests and Coral Reefs. Science, 199, 1302-1310. http://dx.doi.org/10.1126/science.199.4335.1302

[54] Huston, M. (1979) A General Hypothesis of Species Diversity. American Nature, 113, 81-101. http://dx.doi.org/10.1086/283366

[55] Pringle, R.M. (2008) Elephants as Agents of Habitat Creation for Small Vertebrates at the Patch Level. Ecology, 89, 26-33. http://dx.doi.org/10.1890/07-0776.1

[56] Skarpe, C., Hytteborn, H., Moe, S.R. and Aarrestad, P.A. (2014) Historical Changes of Vegetation in the Chobe Area. In: Skarpe, C., du Toit, J.T. and Moe, S.R., Eds., Elephants and Savanna Woodland Ecosystems: A Study from Chobe National Park, Botswana, John Wiley \& Sons Ltd., Chichester, 43-60. http://dx.doi.org/10.1002/9781118858615.ch4 